Journal of Indonesian Economy and Business

Volume 35, Number 1, 2020, $30-43$

\title{
THE INFLUENCE OF EARLY MARRIAGE ON MONETARY POVERTY IN INDONESIA
}

\author{
Wulansari Dyah Rahayu $^{1^{*}}$, Heni Wahyuni ${ }^{2}$ \\ ${ }^{1}$ Department of Economics, Faculty of Economics and Business, Universitas Gadjah Mada, \\ Yogyakarta, 55281, Indonesia \\ $2^{2 *}$ Department of Economics, Faculty of Economics and Business, Universitas Gadjah Mada, \\ Yogyakarta, 55281, Indonesia
}

\begin{tabular}{|c|c|}
\hline ABSTRACT & ARTICLE INFO \\
\hline $\begin{array}{l}\text { Introduction/Main Objectives: The aim of this study is to analyze the } \\
\text { influence of early marriage on monetary poverty in Indonesia. } \\
\text { Background Problems: Recent studies on early marriage show that the } \\
\text { prevalence of early marriage in Indonesia reached } 13.5 \text { percent (Marshan } \\
\text { et al., 2013) and that early marriage exacerbates poverty, which causes an } \\
\text { increase in the economic burden on the family (Djamilah, 2014), an } \\
\text { increase in family harassment, divorce and individuals not continuing } \\
\text { with their schooling (Putranti, 2012), and an increase in the chance of } \\
\text { poverty by } 31 \text { percent in the United States (Dahl, 2010). However, most } \\
\text { studies are qualitative studies. Research Methods: This study uses recent } \\
\text { data from the Indonesian Family Life Survey (IFLS), year 2014; with the } \\
\text { sample being women who get married for the first time at less than } 18 \\
\text { years old as a proxy for early marriage; and monthly per capita income as } \\
\text { a measurement of monetary poverty. This study employs a binary method } \\
\text { for the binary dependent variable which is whether the women experience } \\
\text { monetary poverty. Findings/Results: The result shows that the } \\
\text { prevalence of early marriage in Indonesia has reached } 16.36 \text { percent. } \\
\text { Among those, } 46.61 \text { percent of the women who marry in their teens } \\
\text { (before } 18 \text { years old) do not complete the mandated nine years of basic } \\
\text { education, and } 52.35 \text { percent of the women who were married at an early } \\
\text { age do not have a health insurance card. The results of the binary probit } \\
\text { model show that early marriage does not affect the possibility of a } \\
\text { woman experiencing monetary poverty. It means that early marriage does } \\
\text { not influence the monthly per capita income of the women. Conclusion: } \\
\text { The results of this study imply that other measurements of poverty may } \\
\text { need to be considered. Therefore, the policies that are aimed at reducing } \\
\text { early marriage should consider the impact of other factors on poverty. }\end{array}$ & $\begin{array}{l}\text { Article history: } \\
\text { Received in } 4 \text { January } \\
2019 \\
\text { Received in revised form } \\
\text { 13 June } 2019 \\
\text { Received in revised form } \\
25 \text { February } 2020 \\
\text { Accepted } 28 \text { February } \\
2020 \\
\text { Keywords: } \\
\text { early marriage, monetary } \\
\text { poverty, probit, IFLS, } \\
\text { Indonesia } \\
\text { JEL Code: } \\
\text { - }\end{array}$ \\
\hline
\end{tabular}

\footnotetext{
* Corresponding Author at Department of Economics, Faculty of Economics and Business, Universitas Gadjah Mada, Jalan Socio Humaniora No. 1, Yogyakarta 55182, Indonesia.

E-mail address: wulansari_rahayu@mail.ugm.ac.id(author\#1), hwahyuni@ugm.ac.id(author\#2)
} 


\section{INTRODUCTION}

Poverty is a complex issue facing all countries. Although many studies and research have been conducted, the standard definition of poverty is hard to find (Arsyad, 2010: 299). This is due to the complexity of the topic. Almost all social discipline sciences pay attention to this issue, such as economics, sociology, anthropology, psychology, and politics (Austin, eds, 2006: 3).Therefore, poverty can be analyzed from many aspects.

Poverty is divided into structural poverty and cultural poverty, according to the causes of poverty (Arsyad, 1992). According to the structural view, the economic system that develops in society and strategies to boost development sometimes cannot touch all the layers of society, therefore there are some people who cannot access the factors of production, and this causes poverty. Meanwhile, cultural poverty occurs because the community has not been able to utilize its production factors effectively (Arsyad, 1992). However, fundamentally the causes of structural and cultural poverty cannot be separated due the interaction between both of them.

The concept of absolute (monetary) poverty measures the amount of poverty by comparing the level of income or expenditure of a person with the minimum level of income that a person needs to meet his or her basic needs. Poverty is seen as an economic inability to meet the basic needs for food and not food as measured by expenditure. Furthermore, the minimum expenditure to meet the basic needs is what is called the poverty line. The poor are residents who have an average monthly per capita expenditure below the poverty line (BPS, 2015).

Early marriage is the marriage of people who have not yet reached the age of 18 years old. It is also referred to as one of the social pathologies that cause or exacerbate poverty (UNICEF,
2001). According to Jordan (2004), teen pregnancy which is identified with early marriage, divorce, and crime, are all forms of cultural poverty, a social dysfunction or deficiency experienced by individuals that causes them to be economically weak.

Research into the impact of early marriage on poverty has not been widely conducted. It is caused by the limited data on early marriage, and the theories for structural poverty are more developed than those for cultural poverty (BKKBN, 2012). Dahl's study (2010) provides empirical evidence showing that early marriage has a significant effect on poverty. Dahl (2010) used panel data from 41 states in the United States, and concluded that early marriage increased the likelihood of being poor in the future by 31 percent. Meanwhile, Jordan's research (2004) showed that pregnancy in adolescence did not significantly affect the number of poor people.

In Indonesia, research into the impact of early marriage has been undertaken, for example by Djamilah (2014). The results indicate that early marriage has an impact on increasing the family's economic burden, the divorce rate, domestic violence, reproductive health problems as well as maternal and child mortality. In 2011, the Center for Policy Studies and Population Universitas Gadjah Mada and Plan Indonesia conducted research in six regions of Indonesia. The results of this study indicate that early marriage leads to continued poverty, increased incidences of domestic violence, divorce, and dropping out from school (Putranti, 2012).

Almost all the research into early marriage refers to women as the object of the studies. This is because the incidence of early marriage is more common for women, and women are more vulnerable to the negative impacts of early marriage (eg. Oyortey and Pobi, 2003; Putranti, 2012; Djamilah, 2014). Existing research 
indicates that a woman who had an early marriage will experience more pregnancy risks and lower levels of education than a woman who has not had an early marriage (Putranti, 2012; Djamilah, 2014).

Previous studies show that an early marriage has impacts on many aspects of life, especially the quality of life for the women who experience an early marriage. Therefore, this paper analyzes the impact of early marriage on monetary poverty. Since previous studies use qualitative methods, this study uses a comprehensive quantitative method to analyze the impact. Previous qualitative studies have not been able to quantify the magnitude of the impact; therefore the study of the impact of an early marriage on monetary aspects by this paper can contribute to the knowledge of the impact of an early marriage on the quality of life for people.

\section{Monetary Poverty}

The monetary approach is one form of onedimensional poverty measurement (Alkire and Foster, 2011). The calculation of monetary poverty uses the concept of absolute poverty, which is determined based on the inability of the individual to meet the minimum basic needs necessary to live and work. This minimum requirement is translated into a financial measure in the form of money, where the value of the minimum basic needs is known as the poverty line. Furthermore, people whose expenditure is below the poverty line are classified as poor (BPS, 2015).

The monetary poverty approach is still used by the Central Bureau of Statistics (BPS) to determine who is poor. According to BPS (2015), poverty is seen as an economic inability to meet basic needs for food and non-food.

According to Dartanto and Nurkholis (2011), poverty is influenced by human capital, geographic conditions, demographic factors, and employment status. Dartanto and Nurkholis (2011) found that the increase in human capital shown by having an education has a negative effect on poverty. Geographical conditions, in the form of the location of a person's residence, also determine poverty. A person living in a village is more vulnerable to poverty. Furthermore, demographic factors, in the form of an increase in the number of family members, have a positive effect on poverty. Finally, employment status also determines poverty. A person who is unemployed is more at risk of experiencing poverty than someone with a job.

\section{Early Marriage}

Early marriage or child marriage refers to a marriage conducted before both parties are adults, or a marriage where at least one of the parties is still a child or under the age of 18 years old (BKKBN, 2012). This is in accordance with Article 1989 of the United Nations Convention on the Rights of the Child (CRC) which defines children as all persons under the age of 18 . More than 100 countries in the world have declared under-18 marriage to be a form of early marriage (eg The Inter-African Committee-IAC, Ghana's Children's Act of 1998, Resolution of the Council of the European Parliament and The Convention on the Elimination of All Form of Discrimination Against Women-CEDAW). However, CRC has not yet taken effect in Indonesia. This causes Indonesia to lag behind the majority of countries in the world, in terms of child protection and the prevention of early marriage (BKKBN, 2012).

The provisions of Article 6 paragraph (2) of Law Number 1 Year 1974 on Marriage has actually set the age limit for marriage at 21 years for both men and women. However, Article 7 paragraph (1) of Law Number 1 Year 1974 mentioned that with the permission of the parents, a marriage can be held before the age of 
21 years, ie at 16 years for women and 19 years for men. Furthermore, Article 7 paragraph (2) of Law Number 1 Year 1974 stated that this minimum age limit can be exempted if a dispensation from a religious court is obtained, which can be requested by the parents. With this paragraph, it means there is no minimum age limit for marriage in Indonesia, because according to Mark and Burn (2014, in UNICEF, 2015) 90 percent of the requests for a dispensation are granted, and the number of applicants for this continues to grow. This is in accordance with the results of Hastutiningtyas's (2015) study which showed that there is an increasing level of requests for marriage dispensations submitted to the Religious Court of Yogyakarta.

The Government of Indonesia (GoI), in an effort to prevent child marriage, has actually set forth fresh rules for this in Law No. 23 of 2002 on Child Protection. Article 1 paragraph (1) of Law no. 23 of 2002 states that the definition of a child is someone who has not reached the age of 18 years. Furthermore, Article 26 paragraph (1) mentioned that parents are obliged to prevent a child from being married. But in reality the number of child marriages in Indonesia is still significant.

\section{Impact of Early Marriage on Poverty}

Almost all the family members of early marriage actors will be adversely affected. However, this negative impact has the greatest effect on women. The negative influence of an early marriage can be seen in the education, health, economy, and empowerment of women, which will all lead to poverty.

For the educational aspect, it has been widely demonstrated that early marriage is associated with low levels of education (Maertens, 2013; Field and Ambrus, 2008). The publication by UNICEF (2015) on the occurrence of early marriage in Indonesia shows that women who were married at the age of 15 have lower education levels than those of women married at the age of 18 . In addition, it was also found that many girls who undergo early marriages drop out of school because they have to take care of the household (Putranti, 2012). Jensen and Thornton (2003) said that marriage is a limitation on women getting a higher education. Therefore, many studies recommend increasing school participation as one way to reduce early marriage (Smith et al., 2012).

For the health aspect, early marriage will impact on a range of health problems, such as depression caused by forced sexual intercourse, sexual trauma, high risk of pregnancy at a very young age, high maternal and infant death rates, high risk of HIV transmission, sexually transmitted diseases, and cancer (Fadlyana and Larasaty, 2009; Smith et al., 2012). In the case of early marriage, adolescents are still growing, so if a pregnancy occurs, there will be a competition with the fetus for nutrition (Unicef, 2015; Oyortey and Pobi, 2003). This condition results in the occurrence of anemia and nutritional deficiencies that can cause a low birth weight. Research undertaken by Fadlyana and Larasaty (2009) showed that 14 percent of babies born to teenage mothers aged less than 17 years old experienced a premature birth. In turn, psychologically, the children of teenage parents (who have no experience of life) are at risk of mistreatment, developmental delay, low IQ, learning difficulties, and behavioural disorders (Fadlyana and Larasaty, 2009).

For the economic aspect, women who are married early will lose the opportunity to improve their skills and have good jobs (Singh and Samara, 1996; UNICEF, 2015). As well as losing the opportunity to continue their education, women lose job opportunities because they have to take care of the household. With 
their low educational background, knowledge, and skills, the employment opportunities which exist for these girls are only in low wage jobs (Damayati, 2015). Early marriage also affects the fertility of the women, prolonging the period of sexual activity, which has implications for high numbers of offspring (Oyortey and Pobi, 2003). This condition will cause a population explosion that may increase the burden on the family's economy.

Divorce is also one of the consequences of early marriage (Singh and Samara, 1996). Jones's research (2001) in Madura, East Java shows that many divorces occur within a short span of time after the marriage. This is in accordance with Damayati's (2015) research in the Sungai Keruh Sub-district of Musi Banyuasin Regency that shows 38 percent of early marriages end in divorce, even many divorce occur at the age of marriage is below 5 years. The impact of early marriage is also felt when the age gap between husband and wife is large (Jensen and Thornton, 2003). If the husband dies, the girl/young woman must bear the burden of the family's life.

Early marriage also makes women lose their independence. Many women who get married early lose the opportunity to participate in determining household decisions. This means women cannot refuse if their husband wants sex, they also cannot determine when they will have children. In addition, women also face the risk of losing their close friends, networks, and community (Jensen and Thornton, 2003; Singh and Samara; 1996).

Several studies into early marriage in Indonesia show that people who have experienced early marriage have a high risk of experiencing a low socioeconomic status for their families (e.g Savitridina, 1997; Putranti, 2012; Djamilah, 2014, and Damayati, 2015). However, the existing research has rarely measured the effect of early marriage on monetary poverty quantitatively. Therefore, this study is designed to measure the effect of early marriage on monetary poverty in Indonesia.

\section{DATA AND METHOD}

This study uses secondary data from the Indonesian Family Life Survey, 2014 (IFLS5). IFLS data provide comprehensive longitudinal survey data on individuals, households, and communities in Indonesia. The respondents are from 13 provinces in Indonesia and represent more than 83 percentage of the population in Indonesia. IFLS wave 5 year 2014 is the latest data published by RAND in cooperation with the Center for Policy Studies and Population Universitas Gadjah Mada and Survey METRE. The data sources for this study are samples of married women aged 15 and older.

The dependent variable in this research is poverty, which is measured from the monetary aspect. The poverty line used in this study refers to the measurement conducted by the Central Body of Statistics or BPS (2015). BPS established the total urban and rural poverty line for the period of March 2015 to be 330,776 rupiah. With this measurement, the monetary poverty is defined as individuals who have an average monthly expenditure below 330,776 rupiah. The monetary poverty variable in this study is in the form of a dummy variable, which is equal to one if a person is classed as poor (an average monthly expenditure below 330,776 rupiah), and zero otherwise.

The key independent variable is the incidence of an early marriage. In this study, early marriage refers to a marriage for individuals under the age of 18 years old (BKKBN, 2012). This age limit is chosen because it is the most used measurement by international agencies such as UNICEF, The Inter-African CommitteeIAC, as well as the European Parliament. Based 
on this definition, the source for the data on early marriage information in the IFLS is obtained from the question of what year did people marry and what year were they born. The calculation of how old someone was when they first married can be obtained by deducting the year of marriage from their year of birth. From this calculation we can identify individuals who experience early marriage. Then, the dummy variable is created, a score of one for individuals who were married before they were 18 , and zero otherwise.

The control variables in this research are the women's education level, age, place of residence, dummy unemployment, and number of family members. Table 1 explains the definition of each variable used in this paper.

In this study, the dependent variables are qualitative, being poor is worth one and not poor is worth zero. Using this model, we use an estimation of the qualitative response model, whose purpose is to find the probability of an event, which in this research is the possibility of someone being poor or not. The most widely used models for qualitative response regressions are the logit and probit models (Gujarati and Porter, 2013: 173). These models are able to guarantee probability estimation values ranging within logical limits, ie. between zero and one.

Logit and probit models use forms of the cumulative distribution function (CDF). The difference is that the logit model uses the logistic distribution function, while the probit uses a normal distribution function. The logit equation's form can be written:

$$
\begin{aligned}
\mathrm{P}_{\mathrm{r}}(\mathrm{x}) & =\mathrm{E}\left(\mathrm{Y}_{\mathrm{i}}\right. \\
& \left.=1 \mid \mathrm{X}_{\mathrm{i}}\right)=\frac{1}{1+e^{-(\beta 1+\beta 2 X 1)}}
\end{aligned}
$$

$\mathrm{Pi}$ is the probability of a successful event ( $\mathrm{Y}=$ 1 ), or a person's probability of being poor. Parameter values are symbolized by $\beta 2$. The equation can then be written:

$\mathrm{P}_{\mathrm{i}}=\frac{1}{1+e^{-Z i}}=\frac{e^{z i}}{1+e^{z i}}$

$Z_{i}=\beta_{1}+\beta_{2} X_{i}$

$\mathrm{Zi}$ is known for its logistics distribution function. If $\mathrm{Pi}$ is the probability of a person's success being unlikely, the likelihood of an event failing or someone not being poor is (1-Pi). This can be written as:

$$
\begin{aligned}
& 1-\mathrm{P}_{\mathrm{i}}(\mathrm{x})=1-\frac{e^{z i}}{1+e^{z i}} \\
& \frac{P i(x)}{1-P i(x)}=\frac{1+e^{z i}}{1+e^{-Z i}}=\mathrm{e}^{\mathrm{zi}}
\end{aligned}
$$

\begin{tabular}{|c|c|}
\hline $\begin{array}{l}\text { Variable } \\
\text { (Notation) }\end{array}$ & Definition \\
\hline Monetary Poverty (d_MonetaryPov) & $\begin{array}{l}\text { Dummy variable: }=1 \text { if individual has expenditure of less than } \\
\text { Rp330,776; }=0 \text { if otherwise. }\end{array}$ \\
\hline Early Marriage (d_EarlyMar) & $\begin{array}{l}\text { Dummy variable: }=1 \text { if the individual was first married at the age of }< \\
18 \text { years; }=0 \text { if otherwise. }\end{array}$ \\
\hline Level of Education $(E d u c)$ & Number of years the woman spent in education. \\
\hline Age (Age) & The current age in years. \\
\hline Place of Residence (d_Rural) & Dummy variable of place of residence: $=1$ if village; $=0$ if city \\
\hline Unemployment (d_UnEmploy) & $\begin{array}{l}\text { Dummy variable for individuals who do not work: }=1 \text { if one does not } \\
\text { work; }=0 \text { if otherwise. }\end{array}$ \\
\hline Household size (HHsize) & The number of family members \\
\hline
\end{tabular}

Table 1. Operational Definition of Research Variables 
$\mathrm{P}_{\mathrm{i}} / 1-\mathrm{P}_{\mathrm{i}}$ is an odds ratio (probability ratio) for the possibility of a woman who married young being poor. Odds ratios are a measure of the tendency to experience a successful event, which is also the ratio between the probability of being poor or not being poor. This value is obtained by performing an antilog on the logit's estimation result. If it is transformed into a natural logarithm, the equation is obtained:

$\mathrm{L}_{\mathrm{i}}=\ln \left(\frac{P i}{1-P i}\right)=\mathrm{Z}_{\mathrm{i}}=\beta_{1}+\beta_{2} \mathrm{X}_{1}$

$\mathrm{L}_{\mathrm{i}}=\ln \left(\frac{P i}{1-P i}\right)=\beta_{1}+\beta_{2} \mathrm{X}_{1}+\mathrm{u}_{\mathrm{i}}$

Equation 7 is linear in $\mathrm{X}$ and in the parameter, and it is called a logit equation. In contrast to the linear regression model which uses the OLS method as a parameter estimator, a logistic regression model uses the maximum likelihood estimation method to estimate the parameters. Maximum likelihood estimates show a value for each parameter that gives the greatest possibility, and are asymptotically normal, natural, consistent, and effective (Wooldridge, 2013: 564).

Meanwhile, the probit model, also known as the NORMIT model equation, is one of the cumulative distribution function (CDF) models. This model is used for determining the probability of individuals experiencing a successful event based on the value of the group of independent variables that are used in this study.

The probit model is used by following several assumptions: 1) The probability of a successful event depends on the latent variable or the unobserved variable, which is determined by the explanatory variable, where the greater the unobserved value is, the greater the chance of success is. 2) There is a critical value for the unobserved variable, so that if the unobserved variable passes this critical level, the event is a success and vice versa. The unobserved critical value equals the unobserved variable, with the assumption that a normally distributed critical value has the same mean and variance (Suwardi, 2011).

Using the assumption of normality, the probability of a critical value $\mathrm{I}_{i}{ }^{*}$ less than or equal to an unobserved variable can be calculated by the CDF. The chance of success is determined by the unobserved utility value $I_{i}$ variable. The probit model is:

$$
\begin{aligned}
\mathrm{F}\left(\mathrm{I}_{\mathrm{i}}\right) & =\frac{1}{\sqrt{2 \pi}} \int_{-\infty}^{I_{i}} e^{-z^{\frac{2}{2}}} d z \\
& =\frac{1}{\sqrt{2 \pi}} \int_{-\infty}^{\beta 1+\beta 2 X} e^{-z^{\frac{2}{2}}} d z
\end{aligned}
$$

If $\mathrm{P}$ is a probability of success, the normal default value is between $-\infty$ to $\mathrm{I}_{\mathrm{i}}$. The estimation of $I_{i}$ is obtained by inversing the normal cumulative function, so that it is obtained:

$$
\begin{aligned}
I_{i} & =F^{-1}\left(I_{i)}=F^{-1}\left(P_{i}\right)\right. \\
& =\beta_{0}+\beta_{1} X_{1}+\beta_{2} X_{2}+\ldots B_{k} X_{k}
\end{aligned}
$$

Similar to the logistic regression analysis model, the probit's parameter ( $\beta$ ) also uses the maximum likelihood (ML) method. The ML $\beta$ estimator is an unbiased estimator and approximates the normal distribution for a large sample. Similarly, the value of the probit's coefficient also cannot be interpreted directly, because the probability value follows the normal distribution $Z$. Direct interpretation can only be done for the coefficient signs of the independent variables. The way to interpret the probit model's coefficient is to calculate the change in the probability value with the marginal effect (ME), which calculates the change in probability if there is a change in the independent variable. The binary regression model has several statistical test steps to determine the effect of the explanatory variables in the model, such as the simultaneous likelihood ratio test (LR Test) and the partial significance test of the $\mathrm{Z}$ statistics or the Wald test. The LR statistical test is used to test the simultaneous influence of the independent 
variables on the dependent variable (Wooldridge, 2013; Nawangsih and Bendesa, 2013). The statistical value of $G$ or LR follows the chi square's distribution (X2) with the degree of freedom (df) as the number of independent variables. The hypothesis of the statistical tests of $\mathrm{LR}$ or $\mathrm{G}$ is:

$\mathrm{H}_{0}: \beta_{1}=\beta_{2}=\ldots \beta \mathrm{i}$

Simultaneously there is no influence of the independent variable on the dependent variable;

$H_{l}$ : at least $1 \beta \mathbf{j} \neq 0, \mathrm{j}=1,2,3, \ldots$ i.

Simultaneously there is at least one independent variable that affects the dependent variable.

The result shows that $\mathrm{H}_{0}$ is rejected, thus it can be concluded that the independent variables simultaneously and significantly affect the dependent variable.

The partial significance of the independent variables on the dependent variable can be determined by Wald or $\mathrm{Z}$ statistical tests (Wooldridge, 2013, Nawangsih and Bendesa, 2013). The hypothesis of the $Z$ test is:

$\mathrm{H}_{0}: \beta_{\mathrm{j}}=0, \mathrm{j}=1,2,3, \ldots \mathrm{i}$
$\mathrm{H}_{1}: \beta_{\mathrm{j}} \neq 0, \mathrm{j}=1,2,3, \ldots \mathrm{i}$

This concept can be done by assuming that the Wald test follows the distribution of chi square with degrees of freedom equal to one. The result indicates that $\mathrm{H}_{0}$ is rejected. Therefore, it can be said that the independent variables partially and significantly affect the dependent variable.

According to Dahl (2010), and Dartanto and Nurkholis (2011), the models built in this research are:

$$
\begin{aligned}
& \text { Logit d_MonetaryPov }_{i}= \\
& \beta_{0}+\beta_{1} d \_ \text {EarlyMar } \\
& { }_{3} \text { Age }_{i}+\beta_{4} \text { Educ }_{4} \text { Rural }_{i}+ \\
& \beta_{5} d_{-} \text {UnEmploy } \\
&
\end{aligned}
$$

Probit d_MonetaryPov ${ }_{i}=$

$$
\begin{aligned}
& \beta_{0}+\beta_{1} d_{-} \text {EarlyMar } \\
& \beta_{3} \text { Age }_{i}+\beta_{2} \text { Educ }_{4} \text { Rural }_{i}+ \\
& \beta_{5} d_{-}+\text {UnEmploy } \\
&
\end{aligned}
$$

Where:

d_MonetaryPov: Individual with expenditure < Rp330,776.00

d_EarlyMar: Dummy early marriage, one if an individual is first married before the age of 18; zero otherwise

$E d u c$ : Level of education of women (years of education)

Age: Age at the time of survey (years)

d_Rural: Dummy residences, one if lives in a village; zero otherwise

d_UnEmploy: Dummy unemployment, one if unemployed; zero otherwise

HHSize: The number of family members in a household

The best model (logit or probit) to choose is determined by the maximum likelihood value (Cameron and Trivedi, 2010: 456). Furthermore, to check the robustness of the results, regression interaction terms will be added, which are early marriage and the level of education.

\section{RESULTS AND DISCUSSION}

The identification of the respondents who were experiencing monetary poverty was done using the BPS (2015) poverty line. About 22.02 percent of the respondents have an average expenditure of under Rp330,776.00 per month, which is classified as experiencing monetary poverty. Furthermore, as many as 77.98 percent of the respondents have an average monthly expenditure which is greater than the poverty line, therefore they are included in the non-poor category. 


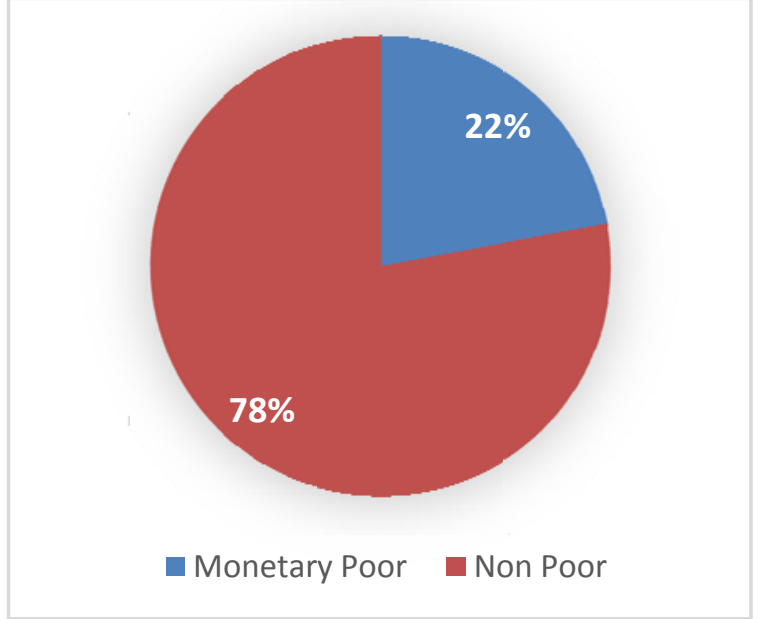

Source: IFLS 5, processed

Figure 1. Percentage of Respondents Experiencing Monetary Poverty

A total of 766 respondents (16.36 percent) identified having an early marriage, or being married before the age of 18 . The age they were first married varied greatly, from the youngest at the age of 11 , to the oldest who was 50 . The average age for their first marriage is 22 . This result is slightly higher than Marshan et al., (2013) study that found the rate of early marriage in Indonesia reached 13.5 percent. On the other hand, these findings are lower than Jones and Gubhaju's (2008) study which suggested that 19 percent of Indonesian women are married at the age of 18 .

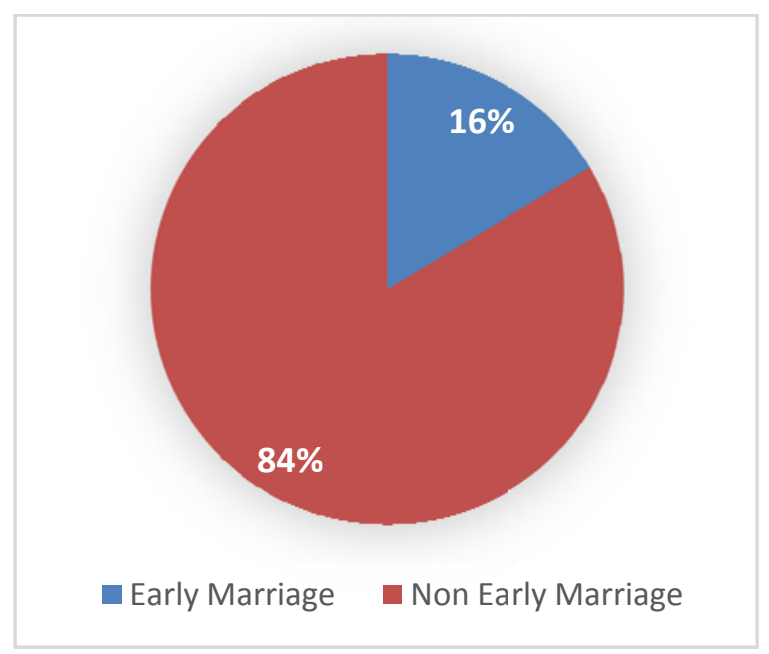

Source: IFLS 5, processed

Figure 2. Percentage of Early Marriages
Of the women who married at or before the age of eighteen, 31.07 percent now find themselves in monetary poverty. This reinforces Putranti's (2012) statement which states that child marriage causes continued poverty. In addition, Djamilah's (2014) study also concluded that early marriage led to an increase in the economic burden; Damayati (2015) and Savitridina (1997) stated that early marriage causes a lower socioeconomic status.

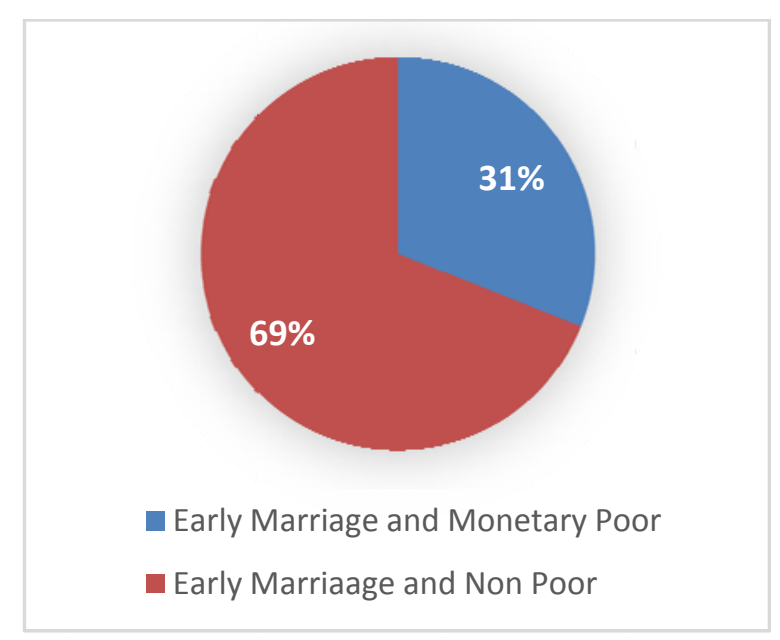

Source: IFLS 5, processed

Figure 3. Percentage of Early Marriage Women in Monetary Poverty

We used the logit and probit regression models to determine the influence of early marriage on monetary poverty. The logit regression result shows that the value of the log likelihood is -2195.998 while the value of the probit log likelihood is -2192.164 . By comparing the log likelihoods to obtain the maximum likelihood, it can be concluded that the probit model is better than the logit model because it has a greater likelihood, with a difference of about 3.834. Table 2 shows the estimation result of the probit's regression. 
Table 2. Estimates of Monetary Poverty Probit

\begin{tabular}{lccccc}
\hline \multicolumn{1}{c}{ Variable } & Coefficient & S.E & PValue & $\begin{array}{c}\text { Marginal Effect } \\
\text { (AME) }\end{array}$ & $\begin{array}{c}\text { Coefficient with } \\
\text { interaction term }\end{array}$ \\
\hline d_EarlyMar & 0.051 & 0.058 & 0.375 & 0.014 & -0.069 \\
Educ & -0.073 & 0.007 & 0.000 & -0.019 & -0.074 \\
& & & $* * *$ & & $* * *$ \\
Age & -0.002 & 0.003 & 0.528 & $-4 \times 10^{-4}$ & -0.001 \\
d_Rural & 0.442 & 0.044 & 0.000 & 0.119 & 0.442 \\
& & & $* * *$ & & $* * *$ \\
d_UnEmploy & 0.109 & 0.047 & 0.019 & 0.028 & 0.109 \\
& & & $* *$ & & $* 0.170$ \\
HHSize & 0.170 & 0.011 & 0.000 & 0.044 & $*$ \\
& & & $* * *$ & & 0.015 \\
d_EarlyMar ${ }^{*} E d u$ & & & & & \\
\hline
\end{tabular}

*significant at level 10 percent, ${ }^{* *}$ significant at 5 percent level, ${ }^{* * *}$ significant at 1 percent level

\section{Probit Significance Test}

The significance tests are performed using a simultaneous significance test with a $G$ test or statistical LR test. The LR statistic test results show that the prob score is $>$ chi2 which is 0.000 or smaller than $\alpha 1$ percent, therefore $\mathrm{H}_{0}$ is rejected at the 1 percent significance level. This means that the independent variables in this study simultaneously and significantly affect the monetary poverty at the 1 percent level of significance.

The partial significance tests for the early marriage variables that are used in the statistical $\mathrm{Z}$ test or the Wald test show that the $\mathrm{p}$ value is 0.375 , therefore $\mathrm{H}_{0}$ is not rejected. These results indicate that there is no significant impact of the early marriage variables on monetary poverty. In other words, early marriage has no effect on the likelihood of a person being poor, from either the financial or the average monthly expenditure aspects. This is in line with the findings of Jordan (2004), which compared the causes of poverty from the structural and cultural aspects. Using aggregate estimates at the national level, Jordan (2004) concluded that there is no effect of pregnancy in adolescence on poverty. Pregnancy in adolescence may indicate that there was an early marriage. According to Jordan, structural aspects such as unemployment, income distribution, and the Gini index are more influential than cultural aspects such as crime rates, and pregnancy in adolescence.

In line with Jordan (2004), Hotz et al., (1999), found that there was no significant impact between pregnancy in adolescence and poverty. According to Hotz et al., (1999) adolescents who get pregnant early have the ability to adapt to the situation. This brings short-term impacts in the form of low levels of education, but over the long term this is compensated for by a longer working life. In the end, adding more working years will provide a higher wage rate. In addition, Hotz et al. (1999) showed that after getting a spouse, early pregnant adolescents earned an income from the spouse, and there was no evidence to suggest that the income of the spouse was lower than when pregnancy was delayed.

Information about the excessive work hours and earnings of husbands in early marriage in this study is difficult to obtain, because most of the respondents did not answer the questions related to work hours. Brown's (1982) study shows that government welfare programs can meet the minimum needs of young pregnant teenagers. All respondents in this study provided 
answers relating to their participation in welfare assistance programs. Furthermore, as many as 25.72 percent of marriage offenders receive assistance from the government's welfare programs, in the form of Direct Cash Assistance (BLT), the Family Hope Program (PKH), as well as Direct Community Support (BLSM).

Information on working hours, the husbands' income, and the acceptance of government welfare programs are actually very important to explain the absence of the effects of early marriage on monetary poverty, on the per capita expenditure side. However, in this study the data about working hours, husbands' income, and the use of credit is very limited.

Furthermore, the results of the probit's regression in this study also indicate that the variables of the level of education, where they reside, unemployment, and the number of family members have significant effects on monetary poverty. Living in a village, being unemployed and a large number of family members all have a positive effect on monetary poverty, while the level of education negatively affects poverty. Meanwhile, the age variable has no effect on monetary poverty.

This finding is consistent with the studies by Sumaryati (2013), Wibowo (2015), and Indriyani (2015), who all found that poverty is a rural phenomenon. In addition, this is also in accordance with Jordan's (2004) study which indicated that unemployment has a positive effect on poverty. Brown's research (1982) also shows that the greater the number of family members there are, the greater the economic burden is, increasing the numbers in poverty. The influence of the level of education on monetary poverty is also in accordance with research by Artha and Dartanto (2014), Erwansyah (2011), and Idorway (2009) which showed that education has a negative effect on poverty. The magnitude of the influence of each variable will be explained through the estimated value of the marginal effect, which is explained in the next section.

\section{Marginal Effect}

According to Cameron and Trivedi (2010: 462), in the nonlinear regression model, the value of the marginal effect is more informative than the coefficient of estimates. This study used the average marginal effect (AME) as a reference, for the reason that it accommodates the change of dummy variables at the discrete level. The results show that when the education level rises by one year, the chances of a woman experiencing monetary poverty fall by 1.9 percentage points. This is in accordance with the study by Artha and Dartanto (2014) which states that the higher the level of education is, the higher the possibility of not being poor is. Furthermore it was found that if a person lives in a village, the probability of experiencing monetary poverty increases by 11.9 percentage points. This is in accordance with research by Artha and Dartanto (2014), Indriani (2015), and Wibowo (2015) who all stated that people living in villages are more vulnerable to poverty.

An unemployed person also had a significant positive effect on the 5 percent degree of confidence in the occurrence of monetary poverty. If someone is unemployed, the likelihood of monetary poverty rose by 2.8 percentage points. Furthermore, if the number of family members rose by one person, the chances of experiencing monetary poverty rose by 4.4 percentage points. This is consistent with Brown's (1982) study, which states that as the population increases, the poverty level increases.

\section{Interaction Term}

Robustness testing of the model to check the influence of early marriage on monetary poverty was done by including the interaction term 
between the variable of early marriage with the level of education. This is done to find the difference in the influence of the level of education on monetary poverty between those who marry young, and those who remain unmarried. The result of the regression with the interaction term indicates that the interaction variable between early marriage and level of education has no significant effect on monetary poverty. This shows that, at the same level of education, there is no difference in the effect of married women with young unmarried women on the possibility of women entering monetary poverty. This reinforces the first model's regression findings that there is no effect of early marriage on monetary poverty.

\section{CONCLUSION}

This study analyzes the impact of early marriage on monetary poverty. The result shows that early marriage is not proven to influence monetary poverty. This suggests that the incidence of early marriage does not affect the difference in the average per capita spending. Given that there has been very little quantitative research into the effect of early marriage on poverty in Indonesia, this research is able to provide an updated picture of the effect of early marriage on poverty in Indonesia. However, there are some limitations that need to be addressed in the future. The limitations are related to the lack of information on women's incomes, working hours, the husbands' income, and the use of credit, making it difficult to get an explanation of the impact of these variables on monetary poverty in Indonesia. This study suggests that future research may consider these variables when analysing monetary poverty.

\section{REFERENCES}

Alkire, S., and Foster, J. 2011. 'Understanding and Misunderstanding of Multidimensional Poverty Measurement'. OPHI Working
Paper 43, Oxford Poverty and Human Development Initiative, Oxford.

Arsyad, L. 1992. 'Memahami Masalah Kemiskinan di Indonesia: Suatu Pengantar'. Jurnal Ekonomi dan Bisnis Indonesia 7 (1).

Arsyad, L. 2010. Ekonomi Pembangunan. Yogyakarta: UPP STIM YKPN.

Artha, D. R. P., and Dartanto, T. 2014. 'Multidimensional Approach to Poverty Measurement in Indonesia'. LPEM-FEUI Working Paper 002, Lembaga Penyelidikan Ekonomi dan Masyarakat Fakultas Ekonomi Universitas Indonesia, Jakarta.

Austin, M. J. (eds), 2006. Understanding Poverty from Multiple Social Science Perspective. Berkeley University of California.

BKKBN. 2012. 'Pernikahan Dini pada Beberapa Provinsi di Indonesia: Akar Masalah dan Peran Kelembagaan di Daerah'. Jakarta.

BPS. 2015. 'Penghitungan dan Analisis Kemiskinan Makro Indonesia Tahun 2015'. Jakarta.

Brown, S. V. 1982. 'Early Childbearing and Poverty: Implications for Social Services'. Adolescence 17 (66): 397-408.

Cameron, A. C., and Trivedi, P. K. 2010. Microeconometrics Using Stata: Revised Edition. Texas: Stata Press.

Dahl, G. B. 2010. 'Early Teen Marriage and Future Poverty'. Demography 47 (3): 689718.

Damayati, N. 2015. 'Pernikahan Usia Dini dan Implikasinya terhadap Keberlanjutan Sumah Tangga di Kecamatan Sungai Keruh Kabupaten Musi Banyuasin Provinsi Sumatera Selatan'. Thesis Unpublished. Yogyakarta: Program Studi Kependudukan Sekolah Pascasarjana UGM.

Dartanto, T., and Nurkholis. 2011. 'Finding Out of the Determinant of Poverty Dynamics in Indonesia: Evidence from Panel Data'. Munich Personal Repec Archive (MPRA), LPEM FEUI, Lembaga Penyelidikan Ekonomi dan Masyarakat Fakultas Ekonomi Universitas Indonesia, Jakarta. 
Djamilah, R. K. 2014. 'Dampak Perkawinan Anak di Indonesia'. Jurnal Studi Pemuda. 3 (1): 1-16.

Erwansyah. 2011. 'Faktor-faktor yang Memengaruhi Kemiskinan di Sumbawa Tahun 2004-2009'. Thesis Unpublished. Yogyakarta: Magister Ekonomika Pembangunan UGM.

Fadlyana, E., and Larasaty, S. 2009. 'Pernikahan Usia Dini dan Permasalahannya'. Sari Pediatri 11 (2): 136-140.

Field, E., and Ambrus, A. 2008. 'Early Marriage, Age of Menarche, and Female Schooling Attainment in Bangladesh'. Journal of Political Economy 116 (5): 881920.

Gujarati, D. N., and Porter, D. C. 2013. Basic Econometrics. New York: Mc. Graw Hill Inc.

Hastutiningtyas, N. 2015. 'Diskresi Dispensasi Nikah Calon Mempelai di Bawah Umur di Pengadilan Agama Yogyakarta (Tahun 2012-2013)'. Thesis Unpublished. Yogyakarta: Jurusan Ilmu Administrasi Negara UGM.

Hotz, V.J., Mcelroy, S. W., Sanders, S.G. 1999. Teenage Childbearing and Its Life Cycle Consequences: Exploiting A Natural Experiment. Massachusetts Working Paper, No. 7397.

Idorway, G. R. L. 2009. Analisis Faktor-faktor yang Memengaruhi Tingkat Kemiskinan di Provinsi Papua Barat Tahun 2004-2008. Tesistidakdipublikasikan. Magister Ekonomika Pembangunan UGM.

Indriyani, L. 2015. 'Analisis Kemiskinan Multidimensi di Provinsi Jawa Tengah Tahun 2011-2013'. Thesis Unpublished. Yogyakarta: Magister Ekonomika Pembangunan UGM.

Jensen, R., and Thornton, R. 2003. 'Early Female Marriage in the Developing World'. Gender and Development 11 (2): 9-19.

Jones, G. W., and Gubhaju, B. 2008. 'Trends in Age at Marriage in the Province of
Indonesia'. ARI Working Paper Series 105, Asia Research Institute, Singapore.

Jones, G. W. 2001. 'Which Indonesian Women Marry Youngest, and Why?' Journal of Southeast Asian Studies 32 (1): 67-78.

Jordan, G. 2004. 'The Causes of Poverty Cultural vs. Structural: Can There Be a Synthesis?' Spring: 18-34.

Maertens, A. 2013. 'Social Norms and Aspirations: Age of Marriage and Education in Rural India'. World Development 47: 1-15.

Marshan, J. N., Rakhmadi, M. F., and Rizky, M. 2013. 'Prevalence of Child Marriage and Its Determinants among Young Women in Indonesia'. Jakarta: SMERU.

Nawangsih, E., and Bendesa, I. K. G. 2013. 'Perbandingan Ketepatan Model Logit dan Probitdalam Memprediksi Kecenderungan Tingkat Hunian Kamar Usaha Akomodasi di Bali 2010'. Jurnal Ekonomi Kuantitatif dan Terapan 6 (1): 62-66.

Oyortey, N. O., and Pobi, S. 2003. 'Early Marriage and Poverty: Exploring Links and Key Policy Issues'. Gender and Development 11(2): 42-51.

Putranti, B. D. 2012. 'Pernikahan Anak di Indonesia'. Yogyakarta: PSKK UGM.

Savitridina. 1997. 'Determinant and Consequences of Early Marriage in Java, Indonesia'. Asia Pacific Population Journal 12 (2): 25-48.

Singh, S., and Samara, R. 1996. 'Early Marriage Among Women in Developing Countries'. International Family Planning Perspectives 22 (4): 148-157+175.

Smith, C. A., Stone, R. P., and Kahando, S. 2012. 'A Model of Women's Educational Factors Related to Delaying Girls' Marriage'. International Rev Education 58: 533-555.

Sumaryati. 2013. Tingkat Kemiskinan Anak dan Faktor-faktor yang Memengaruhinya di Provinsi Sulawesi Barat Tahun 2010-2011. Tesis Tidak Dipublikasikan. Magister Ekonomika Pembangunan UGM. 
Suwardi, A. 2011. Modul Stata: LPM, Logit, dan Probit Model. Laboratorium Komputasi Departemen Ilmu Ekonomi, FE UI.

Unicef. 2001. 'Early Marriage Child Spouses'. Innocenti Digest 7.

Unicef. 2015. 'Child Marriage in Indonesia: Past Progress at a Standstill'. Policy Brief.

Wibowo, A. A. A. 2015. 'Kemiskinan Multidimensi Anak dan Faktor-faktor yang Meme- ngaruhinya di Provinsi Sulawesi Tenggara Tahun 2011 dan 2013'. Thesis Unpublished. Yogyakarta: S2 Magister Ekonomika Pembangunan UGM.

Wooldridge, J. M. 2013. Introductory Econometrics: A Modern Approach. $5^{\text {th }}$ Edition. Canada: South-Western Cengage Learning. 